Bangl. J. Vet. Med. (2006). 4 (1) : 19-26

\title{
PREVALENCE AND CLINICO-PATHOLOGICAL EFFECTS OF ECTOPARASITES IN BACKYARD
} POULTRY

\author{
I. S. Shanta ${ }^{1}$, N. Begum ${ }^{*}$, Anisuzzaman, A. S. M. Bari ${ }^{2}$ and M. J. Karim
}

Department of Parasitology, Faculty of Veterinary Science, Bangladesh Agricultural University, Mymensingh2202, Bangladesh

\begin{abstract}
To study the prevalence of ectoparasites and their clinicopathological effects on backyard poultry, 300 poultry of both sexes and different ages were examined in different areas of Patuakhali district from July 2005 to May 2006. Of them $86.67 \%$ were infested with one or more species of ectoparasites. Six species of lice such as Menacanthus stramineus (74\%), Menopon gallinae (63\%), Lipeurus caponis (48\%), Cuclotogaster heterographus (25\%), Goniodes gigas (18\%), and Goniocotes gallinae (14\%), two species of mites namely Dermanyssus gallinae (57\%), Knemidocoptes mutans, $(43 \%)$ and one species of fly, Simulium sp. (3.7\%) were identified. Among these, M. stramineus was the most common. Aged above 5 months, $100 \%$ poultry were infested with ectoparasites but cocks and broody hens were severely infested. In broody hens, prevalence of $D$. gallinae was the highest $(97.3 \%)$. K. mutans $(43 \%)$ was mostly found in adult poultry aged above two years. The affected birds were emaciated with rough plumage, dandruff, and petechial haemorrhages on the highly infested skin. Small ulcerative lesions were common in Dermanyssus gallinae infestation in which the engorged, red parasites stacked tightly. In K. mutans infestation, legs were rough, swollen with scaly appearance, which was from tibiotarsal joint downwards to the joint of the toes. Some of the severely affected birds showed lameness but no malformation was observed. Histopathologically, scaly leg was characterized by hyperkeratosis and acanthosis. In tissue sections, the mites were observed as transverse or cross section in the deeper parts of the stratum corneum or the superficial layers of the stratum malpighii of the skin and rarely go deeper. In some area of skin, there were losses of epithelium. In advanced cases, there was secondary pyogenic infection; characterized by severe pus cell infiltration in the dermis. The present study suggests that ectoparasitic infestation is very common in the backyard poultry of Bangladesh and they are associated with the production of some clinicopathological effects variable degree.
\end{abstract}

Key words: Prevalence, clinico-pathological effects, ectoparasites, backyard poultry

\section{INTRODUCTION}

Poultry industry development in Bangladesh has taken a quantum leap in the last three decades; however the growth has been mainly restricted to commercial poultry. Rural backyard poultry, though still contributing to the national egg production, are still the most neglected one. Like all other animals, backyard poultry too suffer from a wide range of maladies. In semi-scavenging system, poultry is found to be infested with various types of ectoparasites including different species of lice, mites etc. (Abedin and Huq, 1977; Rahman et al., 1989). The ectoparasites do lower the reproductive success of the birds, and during periods of heavy infestation, may weaken them, lower their resistance. They suck blood, interfere with the feed consumption by giving continuos irritation and thus they are associated with emaciation, anaemia and eventually loss of production. In some cases, severely affected birds may die (Soulsby, 1982).

In our country, only the prevalence of ectoparasites in backyard poultry has been studied. But unfortunately the deleterious effects of ectoparasites on health of backyard poultry have not yet been studied. By considering these points, the present research work was taken to study the over all prevalence of ectoparasites and to study the clinicopathological effect of ectoparasites in backyard poultry.

Present address: ${ }^{1}$ Research Associate, UGC Project entitled " Efficacy of some indigenous plants (aquatic and terrestrial) in controlling vector snails of trematode parasites of medical and veterinary importance, Department of Parasitology, BAU, Mymensignh, ${ }^{2}$ Department of Pathology, Bangladesh Agricultural University, Mymensingh-2202, Bangladesh. 


\section{MATERIALS AND METHODS}

\section{Collection of poultry}

Prevalence of ectoparasites in backyard poultry and their clinico-pathological effects were studied from July 2005 to May 2006 in different areas of Patuakhali. Identification of the parasites and other relevant work were done in the Department of Parasitology, Faculty of Veterinary Science (FVS), Bangladesh Agricultural University (BAU), Mymensingh. The histopathological studies were performed in the Department of Pathology, FVS, BAU, Mymensingh. A total of 300 chickens were purchased from the local markets and farmers' household of the study area.

\section{Collection and identification of ectoparasites}

To study the prevalence of ectoparasites the birds were subjected to antemortem examination. The birds were examined using magnifying glass, for the presence of ectoparasites and any detectable lesions by parting of feathers, by digital palpation and close inspection. Ectoparasites were collected by hand picking and preserved in glycerin alcohol (95 parts of alcohol and 5 parts glycerin) in separate vials for each host. Parasites were identified by preparing permanents slides according to the procedures described by Cable (1957), by using keys and description given by Soulsby (1982) and Wall and Shearer (1997).

\section{Pathological observation}

To study the pathological lesions, seriously affected birds were subjected to postmortem examination. Tissues with severe lesions were collected, preserved in $10 \%$ buffer neutral formalin and processed for histopathology. Histopathological changes were studied by preparing permanent slide according to the description given by Luna (1968).

\section{Statistical analysis}

The prevalence of an ectoparasite in the specific body location(s) was calculated according to the definition of point prevalence (Thrusfield, 1995).

\section{RESULTS AND DISCUSSION}

\section{Prevalence of ectoparasites in backyard poultry}

During the present study, 300 poultry belonging to different age groups were examined, of which 260 $(86.67 \%)$ poultry were infested with one or more species of ectoparasites (Fig. 1).

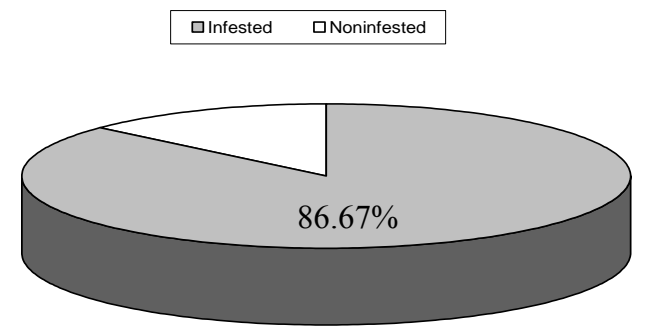

Fig. 1 Prevalence of ectoparasitic infestations in backyard poultry in Bangladesh

High (86.67\%) prevalence of ectoparasites belonging to nine different species as recorded in this study is more or less similar to the previous studies at home (Abedin and Huq, 1970) or elsewhere in the world (Soulsby, 1982, Abebe et al., 1997, Permin et al., 2002; Saxena et al., 2004), which recorded anything from lowest 56.5\% (Koroglu et al., 1999) to a highest 100\% (Permin et al., 2002) from different parts of the world. Saxena et al. (2004) reported $60.9 \%$ lice infestation in fowls in neighbouring India. There had been a difference in the percentage of infestation with lice in male and female chickens as reported by Okursoy and Yilmaz (2002) who recorded $80.6 \%$ and $59.4 \%$ infestation in cocks and hens respectively. Koroglu et al. (1999) examined 600 chickens and found that $56.5 \%$ birds were infested with one or more species of lice in Turkey. Martinez et al. (2001) observed that $91 \%$ poultry were affected with ectoparasites in Venezuela. The apparent 
differences in percentage of infestation justified by the fact that the studies had been undertaken in different parts of the world and the methods of husbandry were different. Nevertheless, the climatic condition, method of study, age and breed/species of poultry and sample size also may be likely contributory factors.

Besides, the village poultry are mostly neglected and reared only a little or no extra feed supplement, and improper housing that makes them malnourished. The keeping condition is also very unhygienic, often crowded in a small place with little or no ventilation. All these factors either alone or in combination might have important role in the high prevalence of ectoparasites in backyard poultry.

In the present study, recording of $100 \%$ infestation (260 out of 260), often severely, in birds over 5 months is not unexpected. Since birds of this age and above scavenge through a wider area of the farmers' house that makes them more exposed to the source of infestation. Although the root causes of high infestation rate with ectoparasites in adult poultry is a little mystery and little understood, there are hypothesis that in extensive management systems, where the chickens have access to outdoor areas and not confined, do have a greater diversity of parasites (Abebe et al., 1997). Also some lice like shaft louse of poultry (M. gallinae) does not develop to appreciable population until the birds are well feathered (Urquhart et al., 1996).

Nine species of ectoparasites were identified of which 6 species were lice such as Menacanthus stramineus (74\%), Menopon gallinae (63\%), Lipeurus caponis (48\%), Cuclotogaster heterographus (25\%), Goniodes gigas (18\%) and Goniocotes gallinae (14\%), one species was fly, namely Simulium sp. (3.7\%), and two species were mites such as Dermanyssus gallinae (57\%) and Knemidocoptes mutans (43\%) (Table 1). The parasitic loads varied from 1 to 25 in sq inch in highly affected body area of each bird. Recording of $M$. stramineus was the most common (74\%) ectoparasites in this study agreed with previous observation by Martinez et al. (2001) and Koroglu et al. (1999). M. stramineus is a very active and voracious feeder. Their fecundity is high and the lice lay relatively large number of eggs in clusters (Urquhart et al., 1996). Besides, after introduction into a flock the lice can spread from bird to bird very rapidly by contact. Perhaps these factors contributed towards a higher prevalence of $M$. stramineus in backyard poultry.

Table 1. Ectoparasites of poultry with their location and prevalence

\begin{tabular}{|c|c|c|c|c|}
\hline \multirow[t]{2}{*}{ Orders } & \multirow[t]{2}{*}{ Name of parasites } & \multirow[t]{2}{*}{ Locations } & \multicolumn{2}{|c|}{ Prevalence* } \\
\hline & & & No. & $\%$ \\
\hline \multirow[t]{6}{*}{ Phthiraptera } & Menacanthus stramineus Nitzsch, 1818, Fig. 2 & Breast, thigh & 222 & 74 \\
\hline & Menopon gallinae Linne, 1758, Fig. 3 & Every part of the body & 189 & 63 \\
\hline & Lipeurus caponis Linn, 1758, Fig. 4 & $\begin{array}{l}\text { Large wing feathers, head, } \\
\text { feathers of cock }\end{array}$ & 144 & 48 \\
\hline & Cuclotogaster heterographus Nitzsch, 1866, Fig. 5 & Head, neck & 75 & 25 \\
\hline & Goniodes gigas Taschenberg, 1879, Fig. 6 & Body and feather & 54 & 18 \\
\hline & Goniocotes gallinae de Geer, 1778, Fig. 7 & Base of feathers & 42 & 14 \\
\hline \multirow[t]{2}{*}{ Arachnida } & Dermanyssus gallinae Degeer, 1778, Fig. 8 & $\begin{array}{l}\text { Rapidly moving through out } \\
\text { the body some stacked in the } \\
\text { skin ulcer }\end{array}$ & 171 & 57 \\
\hline & Knemidocoptes mutans Robin, 1860, Fig. 9 & Legs & 129 & 43 \\
\hline Diptera & Simulium spp, Latreille, 1804, Fig. 10 & Breast and abdomen & 11 & 3.7 \\
\hline
\end{tabular}

*Poultry population for study was 300 .

Finding of fully engorged Simulium sp. on the body of the poultry was interesting. It was almost black in colour but the abdomen was red as the fly was fully engorged with blood. Thorax was humped over the head. Antennae were long with 11 segments but not plumose. The wings were broad and they had no scales and hairs except for bristles on the thick anterior veins. The body was covered with short golden or silvery hairs. These morphological characteristics conform to the morphology of Simulium sp given by Soulsby (1982), Lapage (1962) and Wall and Shearer (1997). The flies like Simulium usually visit the host for a blood meal, and 


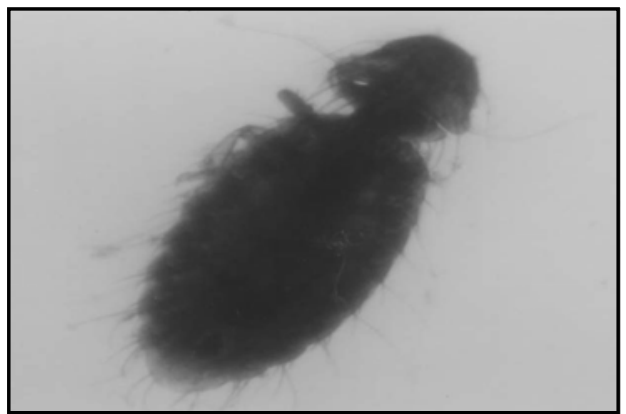

Fig. 2. Menacanthus stramineus Nitzsch, 1818

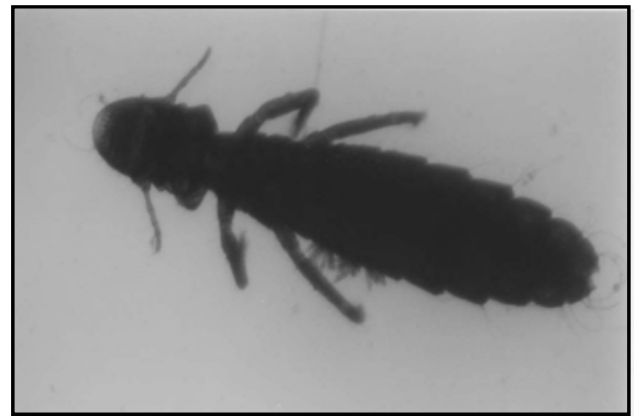

Fig. 4. Lipeurus caponis Linne, 1758

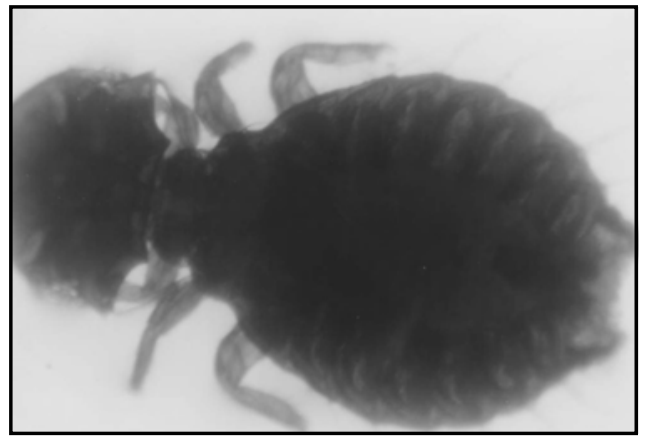

Fig. 6. Goniodes gigas Taschenberg, 1879

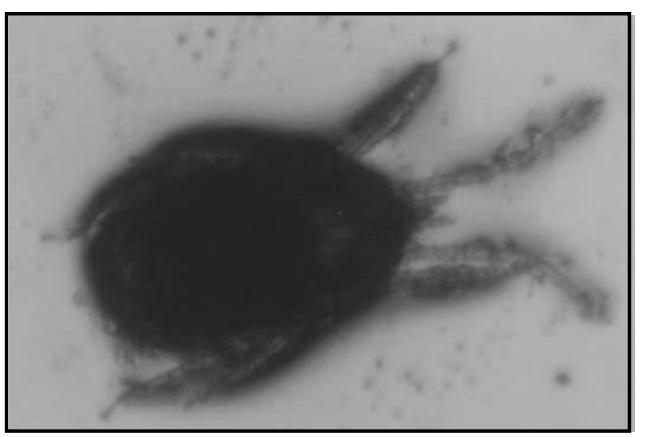

Fig. 8. Dermanyssus gallinae de Geer, 1778

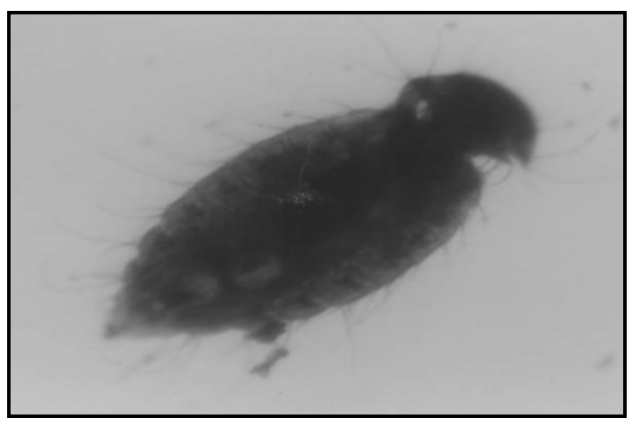

Fig. 3. Menopon gallinae Linne, 1758

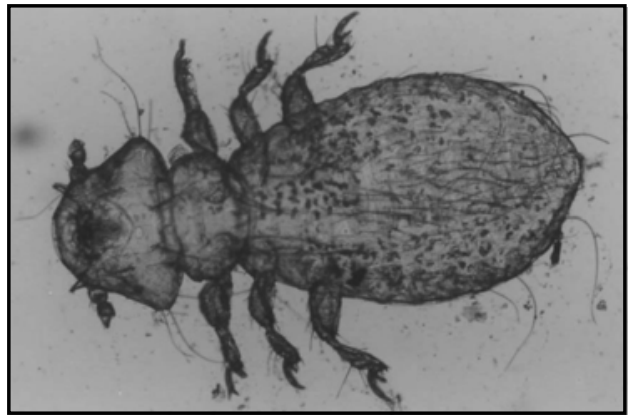

Fig. 5. Cuclotogaster heterographus Nitzsch, 1866

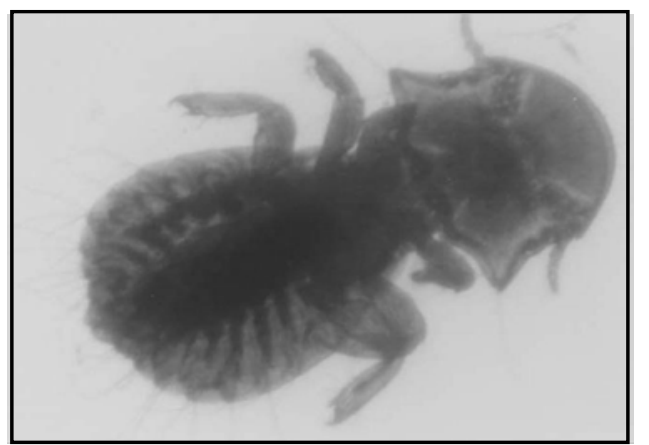

Fig. 7. Goniocotes gallinae de Geer, 1778

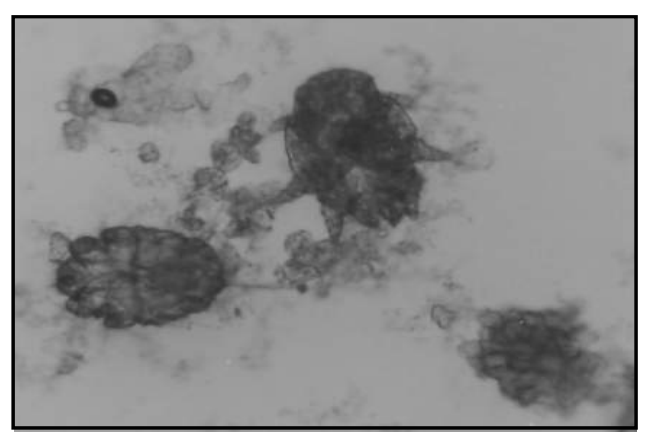

Fig. 9. Knemidocoptes mutans Robin, 1860 
Prevalence of ectoparasites in poultry
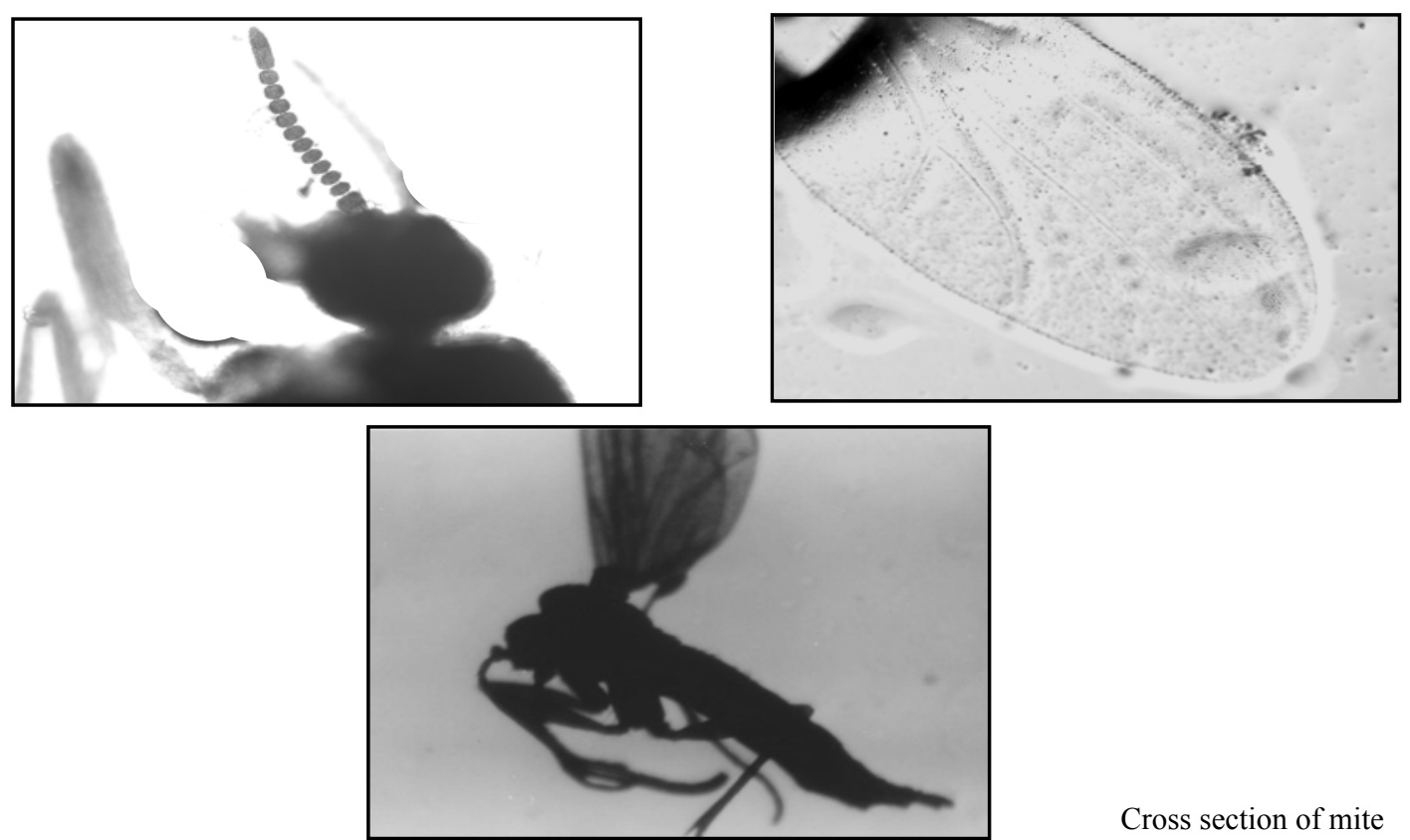

Cross section of mite

Fig. 10. Simulium sp. with antenna and wing Latreille, 1804

Acanthosis

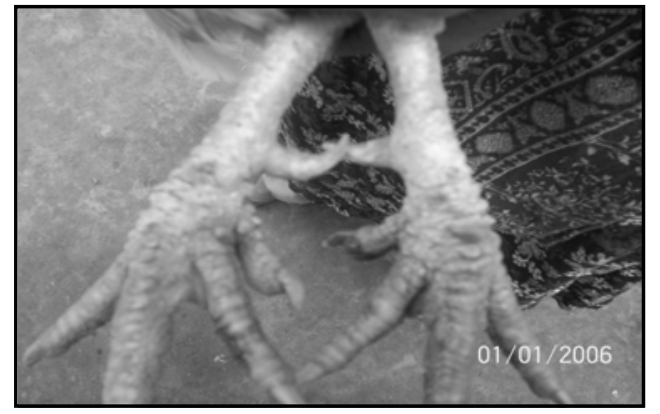

Fig. 11. Scaly appearance of legs affected with K. mutans

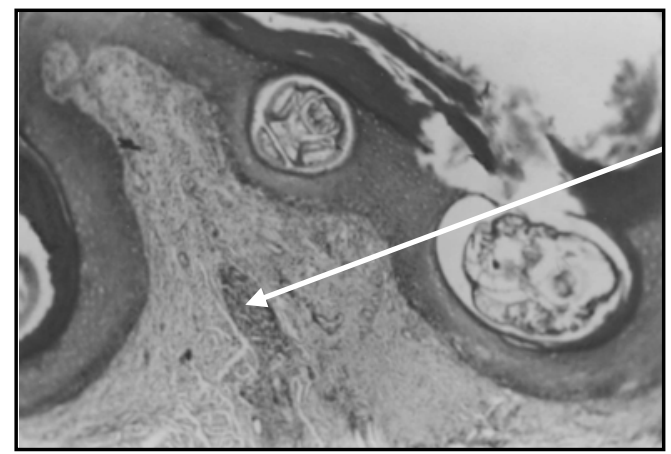

Hyperkeratosis

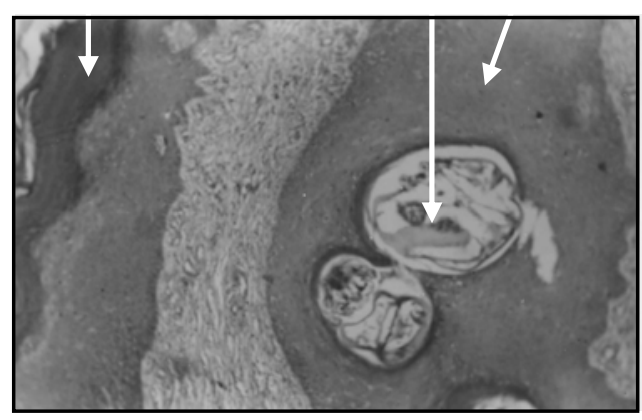

Fig. 12. Hyperkeratosis and acanthosis in the skin of affected legs showing cross section of mite, K. mutans (10x)

Pus cells infiltration

Fig. 13. Purulent dermatitis in the advanced stage of scaly leg mite infestation $(10 \mathrm{x})$ 
it is very likely that once disturbed they would fly away from the host. But the flies were so heavily engorged that they possibly lost their capability of flying, at least for the time being. This is well known for as a cause of great annoyance and irritation. Regular blood meal by few flies may lead to anaemia (Soulsby, 1982). The fly also bites human being, and injects anticoagulants into the feeding site that can leads from mild to severe allergic reactions in sensitive individuals. Moreover the fly can also be a vector of Leucocytozoon caulleryi, an avian malarial parasite. Therefore, recording of the fly bears special significance. It would be interesting to study further about the possible effect of these flies in human, especially bites related allergy.

Relatively more severe infection in broody hens and cocks as revealed in this study agrees with the previous observations by other workers. Okursoy and Yilmaz (2002) recorded severe infestation in cocks with lice. Although the cause of high infestation rate of ectoparasites in cocks and hens cannot be exactly explained but it is observed that male sex hormone make the individual more susceptible to the parasitic infection and mean parasitic burden is high in male (Ackert and Dewhirst, 1950; Todd and Hollingsworth, 1951). On the other hand, broody hens usually pass more time in incubation and less devoted in grooming, preening, parching and rocking. They mostly remain in the nests. Besides, it is well known that increased level of prolactin and progesterone $\left(\mathrm{P}_{4}\right)$ depress the immune system of the individual (Lloyd, 1983). In broody hen prolactin level is usually high (Jiang et al. 2005). This probably explains why the broody hens were more severely infested. In broody hens, prevalence of Dermanyssus gallinae was the highest and it was $97.31 \%$ (34 out of 35).

\section{Clinical and pathological effects of ectoparasites on backyard poultry}

In this study, it was observed that ectoparasites had adverse effects on backyard poultry. The infested birds were emaciated, indicated by the prominence of keel bone, atrophy of thigh muscle. The affected birds had rough plumages and the skin palp had plenty of dandruffs. Petechial haemorrhages were found on the skin of birds those had severe infestation with lice. Small ulcerative lesions were common in Dermanyssus gallinae infestation in which the engorged, red parasites stacked tightly. Simulium sp. was observed on the body of the birds, which were fully engorged with blood. In adverse effect in terms of morbidity such as emaciation, atrophy of thigh muscle and breast muscles, roughness of the plumage, deformity of the legs, ulcerative lesions, petechial haemorrhages on the skin, etc as observed in the birds were very likely due to the results of the ectoparasites infestation. Other scientists in different countries also reported similar findings in poultry. Schihchiang et al. (2004) reported yellow coloured, volcano shaped papules on the skin under the wings and legs of poultry due to chigger's mites' infestation. Islam et al. (1999) recorded restlessness, feather and skin damages and decreased feed intake due to Lipeurus caponis infestation in layer in Bangladesh. Cosoroaba (2001) found significant decrease in egg production and increased mortality due to Dermanyssus gallinae infestation in layer. Bruneau et al. (2001) identified the red mite of poultry, D. gallinae, as one of the most economically important ectoparasites in layer hens in France. Although the exact mechanisms of the major pathological changes are not known but it is well known that poultry lice bites the birds, eat off host tissues, secretions of quill feathers, etc. Their biting is usually irritating and painful; poultry become restless resulting decrease in feed intake (Islam et al. 1999, Soulsby, 1982). So, eventually poultry become emaciated. Due to gradual wasting, atrophy of the breast muscle and thigh muscle occur and resulting prominence of keel bone. Probably continuous biting leads to petechial haemorrhages on the skin. K. mutans, infestation, lesions were observed in the epidermal scales from tibiotarsal joint downwards to the joint of the toes. K. mutans was mostly found in adult poultry aged above two years. Legs of the affected poultry were rough, and large and yellowish white crusty materials covered the whole limb up to the toes (Fig. 11). Removal of the crust exposed the inflammed, moist surface of the limbs with white glistening appearance. Some of the severely affected birds showed lameness but no malformation was observed. Same types of gross pathological changes were reported by Soulsby (1982), Lapage (1962) and Urquhart et al. (1996). Knemidocoptes mutans is a burrowing mite (Urquhart et al. 1996), which deeply burrows into the skin of the legs and thus sets up inflammatory reactions. Exudation occurs which in turn become crusty and replaces the normal smooth scales of the legs.

\section{Histopathology}

Histopathology was performed to study the lesions caused by K. mutans. Deep scrapings from the suspected legs showed huge number of turgid globular mites under the surface of the crust (Fig. 9). The parasites pierced the skin underneath the scale, causing an inflammation with exudates that harden the surface and displaced the 
scales. In tissue sections, the mites were observed as transverse or cross section (Fig. 12) in the deeper parts of the stratum corneum or the superficial layers of the stratum malpighii of the skin and rarely go deeper. The characteristic lesions were observed as hyperkeratosis and acanthosis (Fig. 12). In some area of skin, there were losses of epithelium. In advanced cases, there were secondary pyogenic infection; characterized by severe pus cell infiltration in the dermis (Fig. 13 ). This finding agrees with the findings of Lapage (1962). As K. mutans is a burrowing mite, they set up inflammatory reactions during burrowing. Characterization of scaly leg lesions by hyperkeratosis, parakeratosis and acanthosis, as seen in histopathology explains this process of inflammatory changes following the infestation. Presence of the mites in the deeper layer of the epidermis also justifies the relationship of the mite infestation with the pathological changes. This also demonstrates the relationship of this mite with Sarcoptes spp. The lesions described in this study were also described earlier by other workers (Lapage, 1962; Permin and Hansen, 1998).

In this study, prevalence of ectoparasites and their clinicopathological effects on backyard poultry had been studied. But the effects of ectoparasites on the production performance of backyard poultry had not been evaluated which would provide a clear justification of the control program suggested. So this area needs special attention in any future study.

\section{ACKNOWLEDGEMENT}

The authors thankfully acknowledge the financial support of SLDP-2 (Small Holder Livestock Development Project-2), Danida, to conduct the research work.

\section{REFERENCES}

1. Abebe W, Asfaw T, Genete B, Kassa B and Dorchies PH, (1997). Comparative studies of external parasites and gastrointestinal helminthes of chickens kept under different management system in and around Addis Ababa (Ethiopia). Review on Med. Vet. 148: 497-500.

2. Abedin J and Huq MM (1970). Mallophaga-I of domesticated fowl (Gallus gallus) in East Pakistan. M. Sc. (Vet. Sc.) Thesis, East Pakistan Agricultural University, Mymensingh.

3. Abedin J and Huq MM (1977). Survey on Mallophaga of domesticated fowl in Bangladesh. Journal of Agricultural Science 4: 171-173.

4. Ackert JE and Dewhirst LW (1950). Resistance of fowls to parasitism affected by female sex hormone. Journal of Parasitology 36: 16.

5. Bruneau A, Dernburg A, Chauve $\mathrm{C}$ and Zenner L (2001). First in vitro cycle of the chicken mite Dermanyssus gallinae (Degeer, 1778) Utilizing an artificial feeding device. Parasitology 123: 583-589.

6. Cable RM (1957). An Illustrated Laboratory Manual of Parasitology. Burgess Publishing Co., 426, South Sixth Street, Minneapolis 15, Minnesota.

7. Cosoroaba I (2001). Massive Dermanyssus gallinae invasion in battery-husbandry raised fowls. Revue-de-MedecineVeterinaire 152: 89-96.

8. Islam MK, Mondal MMH, Rahman MM, Haque AKMF and Chowdhury MAA (1999). Effects of Lipeurus caponis, Linnaeus, 1758, (Mallophaga: Philopteridae) on laying hens. Veterinary Review Kathmandu 14: 32-33.

9. Jiang RS, Xu GY, Zhang XQ and Yang N (2005). Association of polymorphisms for prolactin and prolactin receptor genes with broody traits in chickens. Poultry Science 84: 839-845.

10. Koroglu E, Saki CE, Aktas M, Dumanli N and Argin M (1999). Distribution of lice in chicken in Elazig region. SaglikBilimleri-Dergisi-Firat-Universiesi 13: 57-60.

11. Lapage G (1962). Moming's Veterinary Entomology. $5^{\text {th }}$ edn., Bailliere, Tindall and Cox Ltd., Britain.

12. Lloyd S (1983). Effect of pregnancy and lactation upon infection. Veterinary Immunology and Immunopathology 4: 153176.

13. Luna LG (1968). Manual of Histopathologic Staining Method of the Armed Forces Institute of Pathology. $3^{\text {rd }}$ edn., McGrow-Hill Book Co., London.

14. Martinez-de-Chirinos NI, Chirinos AR, Hinestroza Y, Inicarte MF, Manco M, Melendez A and De-Chirinos NI (2001). Prevalence of ectoparasites in domestic fowls (Gallus gallus domesticus) from the San Francisco municipality in Zulia State, Venezuala. Revista-Cientifica,-Facultated-de-Ciencias-Veterinarias,-Universidad- del- Zulia 11: 348-354.

15. Okursoy S and Yilmaz F (2002). Prevalence of species of lice in chickens in the province of Bursa. Turkiye-Parazitoloji Dergisi 26: 71-75.

16. Permin A and Hansen J (1998). The Epidemiology, diagnosis and control of poultry parasites. FAO. Rome, Italy.

17. Permin A, Esmann JB, Hoj CH, Hove T and Mukaratirwa S (2002). Ecto, endo and haemoparasites in free range chickens in the Goromonzi District in Zimbabwe. Preventive Veterinary Medicine 54: 213-224. 
18. Rahman MH, Mondal MMH and Huq MM (1989). A note on the occurances of parasitic mites of domestic fowls in Bangladesh. The Bangladesh Veterinarian 6: 45-47.

19. Saxena AK, Kumar S, Gupta N and Sing SK (2004). Prevalence of lice (Phthiraptera: Amblycera) on fowls of Uttar Pradesh. Journal of Parasitic Disease 28: 57-60.

20. Schihchiang K, Chyichen H, Mingachin K and Robings RG (2004). Trombidiodis in native chickens (Prostigmata: Trombiculidae). Taiwan Veterinary Journal 30: 301-306.

21. Soulsby EJL (1982). Helminths, Arthropods and protozoa of Domesticated Animals. 7th edn., Baillière Tindall, London.

22. Thrusfield M (1995). Veterinary Epidemiology. $2^{\text {nd }}$ edn., Blackwell Science, USA.

23. Todd AC and Hollingsworth KP (1951). Host sex as a factor in development of Ascarida galli. Experimental Parasitology 1: 303-304.

24. Urquhart GM, Armour J, Duncan JL, Dunn AM and Jennings FW (1996). Veterinary Parasitology. $2^{\text {nd }}$ edn., Backwell Science Ltd. London.

25. Wall R and Shearer D (1997). Veterinary Entomology. $1^{\text {st }}$ edn., Chapman and Hall. Great Britain by T. J. International Ltd. Padsfow, Cornwall (72-73). 